\title{
Etnomatematika pada Riasan dan Atribut Bagian Kepala Paes Ageng sebagai Paket Tes Siswa
}

Author:
Amalia Damayanti $^{1}$
Erfan Yudianto $^{2}$
Titik Sugiarti $^{3}$
Yayuk Yudiyati $^{4}$
Affiliation:
1,2,3 University of Jember, East
Java, Indonesia
${ }^{4}$ SMP Negeri 1 Muncar, East
Java, Indonesia
Corresponding author:
Amalia Damayanti,
adaa.amalia@ gmail.com
Dates:
Received: $21 / 6 / 2021$
Accepted: $17 / 7 / 2021$
Published: $23 / 7 / 2021$

\section{Author:}

Erfan Yudianto $^{2}$

Titik Sugiarti ${ }^{3}$

Yayuk Yudiyati ${ }^{4}$

\section{Affiliation:}

${ }^{1,2,3}$ University of Jember, East

Java, Indonesia

${ }^{4}$ SMP Negeri 1 Muncar, East

Corresponding author:

Amalia Damayanti,

adaa.amalia@gmail.com

\section{Dates:}

Received: 21/6/2021

Accepted: $17 / 7 / 2021$

Published: 23/7/2021

\begin{abstract}
Abstrak. Pendidikan merupakan proses perubahan sikap dan perilaku yang diatur menurut kurikulum. Kurikulum memuat beberapa materi pelajaran salah satunya matematika. Namun sebagian besar siswa mengalami kesulitan dalam memahami matematika. Penelitian ini bertujuan untuk mengeksplorasi etnomatemi pada rias wajah dan atribut kepala paes ageng yang dilakukan oleh mempelai wanita di Desa Blambangan Muncar Banyuwangi dan menjadikannya paket tes siswa. Jenis penelitian ini adalah penelitian kualitatif dengan pendekatan etnografi. Metode pengumpulan data yang digunakan adalah observasi dan wawancara. Hasil penelitian ini menunjukkan bahwa terdapat konsep matematika pada riasan dan atribut penampang kepala paes ageng yang meliputi konsep bangun datar dan konsep transformasi geometri. Konsep sosok ceper muncul dalam bentuk atribut dan tata rias pengantin. Konsep transformasi geometri tampak pada peletakan atribut paes ageng. Hasil penelitian ini akan menjadi paket tes siswa.
\end{abstract}

Kata kunci: Etnomatematika, Paes Ageng, Paket Tes Siswa

\begin{abstract}
Education is a process of changing attitudes and behaviors that are organized according to the curriculum. The curriculum contains several subject matter one of which is mathematics. But most students have difficulty in understanding mathematics. This study aims to explore ethnomatemics on the makeup and attributes of the head of paes ageng performed by the bride in the Blambangan Muncar Banyuwangi village and to make it a student test package. This type of research is a qualitative research with an ethnographic approach. Data collection methods used are observation and interviews. The results of this study indicate that there are mathematical concepts on the makeup and attributes of the paes ageng head section including the concept of flat figure and the concept of geometry transformation. The concept of a flat figure appears in the forms of bridal attributes and makeup. The concept of geometry transformation appears in the laying of the paes ageng attribute. The results of this study will be a student test package.
\end{abstract}

Keywords: Ethnomathematics, Paes Ageng, Students Test Package

\section{JoMEaL}

Copyright:

This work is licensed under a Creative Commons Attribution-ShareAlike 4.0 International License.

Read online:

https://jurnal.unej.ac.id/index.php/JOMEAL/index or scan barcode beside.

How to cite this article:

Damayanti, A., Yudianto, E., Sugiarti, T., \& Yudiyati, Y. (2021). Etnomatematika pada Riasan dan Atribut Bagian Kepala Paes Ageng sebagai Paket Tes Siswa. Journal of Mathematics Education and Learning, 1(2), 178-187. Retrieved from https://jurnal.unej.ac.id/index.php/JOMEAL/article/view/24330 


\section{Pendahuluan}

Matematika dalam dunia pendidikan bukan suatu ilmu yang asing lagi. Karena, setiap jenjang pendidikan tidak lepas dari matematika. Matematika sendiri adalah ilmu yang mempelajari tentang bilangan, dan segala sesuatu yang berhubungan dengan menghitung yang mencakup segala bentuk prosedur operasional untuk menyelesaikan masalah seperti besaran, struktur, perubahan-perubahan yang ada pada bilangan, dan geometri. Menurut Alders \& Soemantri (1980) materi geometri adalah materi yang mempelajari tentang bentuk, ruang, sudut, komposisi beserta sifat-sifatnya, ukuranukurannya, dan hubungan antara yang satu dengan yang lain. Namun bagi siswa matematika khususnya geometri sebagai pelajaran yang sukar. Oleh karenanya permasalahan tersebut menjadi pekerjan atau tugas khusus bagi guru sebagai pendidik.

Salah satu strategi yang dapat dilakukan pendidik dalam meminimalisir pandangan awam terhadap matematika adalah dengan memberikan wawasan dan arahan serta pendekatan yang tepat kepada siswa. Salah satunya dengan mengaitkan matematika dengan kebudayaan yang ada di sekitar. Karena kebudayaan dan pendidikan merupakan bagian yang tidak dapat dipisahkan, keduanya saling mendukung dan menguatkan.

Menurut D’Ambrosio (2006) etnomatematika adalah suatu studi tentang pola hidup, kebiasaan atau adat istiadat dari suatu masyarakat di suatu tempat yang memiliki kaitan dengan konsep-konsep matematika namun tidak disadari sebagai bagian dari konsep matematika oleh masyarakat tersebut, misalnya pada riasan dan atribut bagian kepala paes ageng.

Menurut Alders \& Soemantri (1980) materi geometri adalah materi yang mempelajari tentang bentuk, ruang, sudut, komposisi beserta sifat-sifatnya, ukuran-ukurannya, dan hubungan antara yang satu dengan yang lain. Menurut Ruseffendi (1991) geometri itu ialah suatu sistem aksiomatik dan kumpulan generalisasi, model dan bukti tentang bentuk-bentuk benda bidang dan ruang.

Menurut Burger \& Shayghnessy (1986) Geometri menempati posisi khusus dalam kurikulum matematika, karena banyaknya konsep-konsep yang termuat di dalamnya. Dari sudut pandang psikologi, geometri merupakan penyajian abstraksi dari pengalaman visual dan spasial, misalnya bidang, pola, pengukuran dan pemetaan. Dari sudut pandang matematika, geometri menyediakan pendekatan-pendekatan untuk pemecahan masalah, misalnya gambar-gambar, diagram, sistem koordinat, vektor, dan transformasi. Geometri juga merupakan lingkungan untuk mempelajari struktur matematika.

Penelitian yang relevan telah dilakukan sebelumnya oleh Krisnawati (2017) pada pelaksanaan Tradisi Pernikahan Yogyakarta oleh masyarakat di Kecamatan Minggir, Kabupaten Sleman, Provinsi DIY sedangkan Pada penelitian ini lebih mengacu pada riasan dan atribut berupa aksesoris yang dikenakan pengantin di bagian kepala.

Berdasarkan uraian di atas, penelitian ini dilakukan untuk menggali etnomatematika pada pada riasan dan atribut bagian kepala paes ageng. Menghasilkan paket tes terkait dengan etnomatematika pada pada riasan dan atribut bagian kepala paes ageng.

Hasil dari penelitian ini diharapkan membantu guru yang berada dalam lingkup masyarakat Jawa melaksanakan pembelajaran matematika yang kontekstual berkaitan dengan riasan dan atribut bagian kepala paes ageng pada Pengantin Jawa. Dapat digunakan untuk mengetahui keterkaitan antara kebudayaan jawa dengan matematika melalui pembelajaran matematika yang realistik. Mengetahui cara membilang, mengukur, dan menghitung. Dapat dijadikan sebagai acuan bagi penelitian lain yang serupa. Dan diharapkan dapat mengubah opini masyarakat yang berpendapat 
bahwa tidak ada keterkaitan matematika dengan kegiatan sehari-hari mengetahui lebih jelas aspek matematis apa saja yang terdapat pada riasan dan atribut bagian kepala paes ageng. Oleh karena itu, Berdasarkan uraian di atas, penelitian ini dilakukan untuk mengetahui lebih jelas aspek matematis apa saja yang terdapat pada riasan dan atribut bagian kepala Paes Ageng. Oleh karena itu, perlu dilakukan penelitian yang berkaitan dengan etnomatematika, dengan judul "Etnomatematika pada Riasan dan Atribut Bagian Kepala Paes Ageng sebagai Paket Tes”. Dengan rumusan masalah; Bagaimanakah etnomatematika pada riasan dan atribut bagian kepala paes ageng? Bagaimanakah paket tes terkait dengan etnomatematika pada riasan dan atribut bagian kepala paes ageng?

\section{Metode Penelitian}

Pada penelitian ini metode yang digunakan yakni penelitian kualitatif dengan pendekatan etnografi. Menurut Marshall \& Rossman (1995) penelitian kualitatif didefinisikan sebagai suatu proses yang mencoba untuk mendapatkan pemahaman yang lebih baik mengenai kompleksitas yang ada dalam interaksi manusia.

Daerah penelitian adalah tempat yang akan digunakan peneliti untuk melakukan penelitian. Daerah yang digunakan dalam penelitian ini adalah di Desa Blambangan, Kecamatan Muncar, Kabupaten Banyuwangi. Alasan memilih daerah tersebut karena di daerah tersebut pernikahan dengan menggunakan riasan pengantin paes ageng masih bisa ditemui.

Subjek penelitian adalah perias pengantin yang berdomisili di daerah tersebut. Subjek penelitian ini sebanyak 2 orang yaitu perias, dan pemilik sanggar rias.

Definisi operasional digunakan untuk menghindari kesalahan penafsiran dan batasan-batasan permasalahan dalam penelitian agar tidak menimbulkan anggapan lain.

1) Etnomatematika riasan dan atribut bagian kepala paes ageng yang dimaksud adalah perlengkapan riasan pengantin, meliputiti riasan pengantin dan aksesoris bagian kepala yang dikaitkan dengan konsep matematika.

2) Bahan ajar geometri yang dimaksud yaitu berupa paket tes yang berisikan soal-soal terkait etnomatematika riasan dan atribut bagian kepala paes ageng.

3) Paes merupakan riasan yang ada di bagian dahi hingga rambut. Ada berbagai macam jenis Paes di Indonesia namun dalam penelitian ini menggunakan jenis paes ageng yang biasa dikenakan oleh putra-putri kebesaran Yogyakarta di masa silam.

Prosedur penelitian merupakan semua tahap untuk mencapai tujuan dalam penelitian ini, maka langkah-langkah yang digunakan adalah sebagai berikut. Pendahuluan, Pada tahap pendahuluan dilakukan penentuan permasalahan yang nantinya dijadikan sebagai objek penelitian. Pada tahap ini juga memastikan kesediaan pemilik sanggar dan perias untuk dijadikan subjek penelitian. Langkah kedua pengumpulan data merupakan langkah yang paling strategis dalam penelitian, karena tujuan utama dari penelitian adalah mendapatkan data (Harsya \& Ernawaty, 2017). Menurut Nazir, (2003) observasi adalah pengumpulan data atau dengan pengamatan langsung adalah cara pengambilan data dengan menggunakan mata tanpa pertolongan alat standar lain untuk keperluan tersebut. Selanjutnya membuat instrumen berupa pedoman observasi (Lampiran 2) dan pedoman wawancara (Lampiran 4). Pedoman observasi digunakan untuk mengidentifikasi konsep atau unsur geometri yang terdapat pada atribut pernikahan yang tersedia di Griya Rias Wimma antara lain bangun datar dan transformasi geometri, Pedoman wawancara digunakan untuk memperoleh data dari pemilik sanggar dan perias di Griya Rias Wimma, dimana pertanyaan yang terdapat dalam pedoman wawancara merupakan pertanyaan secara garis besar saja dan dapat berkembang pada saat melakukan wawancara langsung. 
Menurut Sarwono, (2006) analisis data dalam penelitian kualitatif bersifat induktif dan berkelanjutan yang tujuan akhirnya menghasilkan pcngertian-pengertian, konsep-konsep dan pembangunan suatu teori baru. Sebelum terjun ke lapangan instrument divalidasi oleh dua dosen pendidikan matematika. Selanjutnya hasil dari validasi oleh validator akan dianalisis kevalidannya.

Validasi dilakukan dengan memberikan instrumen penelitian dan proposal kepada validator yaitu dua orang dosen Program Studi Pendidikan Matematika, Universitas Jember. Setelah dikoreksi dan diberikan saran perbaikan oleh validator maka dilakukan revisi sesuai dengan saran validator hingga instrumen penelitian dinyatakan valid. Mengumpulkan data, Selanjutnya, instrumen yang telah valid tersebut dapat digunakan untuk mengumpulkan data terkait etnomatematika pada riasan dan atribut bagian kepala paes ageng dengan melakukan observasi dan wawancara. Kegiatan observasi dilakukan dengan cara mengamati atribut dari bagian-bagian masjid sesuai dengan lembar observasi. Pengamatan yang dilakukan berkaitan dengan konsep geometri diantaranya lain bangun datar, bangun ruang, transformasi geometri, kesebangunan dan kekongruenan. Observer dalam penelitian ini dilakukan oleh Amalia Damayanti didampingi oleh Aina Kholifatuzzuhro dengan kode subjek P. Kemudian, kegiatan wawancara dilakukan dengan dua orang yaitu Winarti selaku pemilik sanggar dengan kode subjek S3 dan Diah Purnawati selaku perias pengantin dengan kode subjek S4. Wawancara dilakukan di Griya Rias Wimma.

Hasil wawancara yang sudah ditranskrip diberi kode dengan menggunakan huruf kapital yaitu $\mathrm{P}$ yang menyatakan peneliti dan $\mathrm{S}$ yang menyatakan subjek, kemudian diikuti empat digit angka. Digit pertama menyatakan kode dari subjek atau peneliti dan tiga digit terakhir menyatakan urutan percakapan yang terjadi pada kegiatan wawancara. Jika dituliskan P3001 Peneliti bertanya pada subjek ke-3 dengan pertanyaan nomor 001. Demikian seterusnya dan berlaku untuk subjek penelitian yang lain. S3001 Subjek ke-3 menjawab/menanggapi pertanyaan/tanggapan peneliti dengan kode P3001. Setelah melakukan kegiatan observasi dan wawancara, langkah selanjutnya adalah analisis data. Data hasil observasi dan wawancara direduksi kemudian diuraikan dan dianalisis sesuai dengan fokus topik penelitian. Berdasarkan hasil analisis penelitian, lalu langkah selanjutnya yaitu pembuatan paket tes. paket tes tersebut dibuat berdasarkan etnomatematika pada riasan dan atribut bagian kepala Paes ageng. Kemudian langkah yang terakhir adalah melakukan penarikan kesimpulan dari hasil penelitian.

\section{Hasil dan Pembahasan}

Pada penelitian ini, langkah pertama yang dilakukan adalah tahap pendahuluan. Pada tahap pendahuluan dilakukan penentuan permasalahan yang nantinya dijadikan sebagai objek penelitian. Sesuai dengan permasalahan yang diambil maka daerah penelitian yang dipilih yaitu di Griya Rias Wimma. Alasan memilih tempat penelitian tersebut adalah karena di Griya Rias Wimma merupakan salah satu salon perias pengantin yang sudah berpengalaman dalam membantu terselenggaranya pernikahan. Pada tahap ini juga memastikan kesediaan pemilik sanggar dan perias untuk dijadikan subjek penelitian.

Langkah kedua yaitu membuat instrumen penelitian berupa pedoman observasi (Lampiran 2) dan pedoman wawancara (Lampiran 4). Pedoman observasi digunakan untuk mengidentifikasi konsep atau unsur geometri yang terdapat pada atribut pernikahan yang tersedia di Griya Rias Wimma antara lain bangun datar dan transformasi geometri. Pedoman observasi juga digunakan untuk mengetahui adanya konsep atau unsur geometri pada riasan dan atribut bagian kepala paes ageng 
dapat dijadikan acuan pembuatan pedoman wawancara. Pedoman wawancara digunakan untuk memperoleh data dari pemilik sanggar dan perias di Griya Rias Wimma, dimana pertanyaan yang terdapat dalam pedoman wawancara merupakan pertanyaan secara garis besar saja dan dapat berkembang pada saat melakukan wawancara langsung. Instrumen penelitian yang telah dibuat tersebut lalu divalidasi oleh validator. Validasi dilakukan dengan memberikan instrumen penelitian dan proposal kepada validator yaitu dua orang dosen Program Studi Pendidikan Matematika, Universitas Jember. Setelah dikoreksi dan diberikan saran perbaikan oleh validator maka dilakukan revisi sesuai dengan saran validator hingga instrumen penelitian dinyatakan valid.

\section{Analisis Konsep Bangun Datar}

Konsep bangun datar muncul pada bentuk-bentuk dari riasan dan atribut bagian kepala paes ageng terdapat 4 bentuk bangun datar yang ditemukan pada penelitian ini yaitu, lingkaran, belah ketupat, segitiga dan poligon.

Analisis berikut merupakan hasil observasi oleh observer dan wawancara dengan S3 dan S4 selaku pemilik dan perias pengantin. Berdasarkan hasil observasi oleh peneliti dengan diperoleh bahwa pada riasan dan atribut bagian kepala Paes ageng terdapat konsep bangun datar diantaranya pada bagian kuluk, sumping, paes ageng, cithak, sisir gunungan, suweng.

Konsep bangun datar lingkaran muncul pada bentuk-bentuk dari riasan dan atribut bagian kepala paes ageng diantaranya kuluk, sumping, suweng dan sisir gunungan. Berikut merupakan cuplikan pertanyaan dan jawaban mengenai bangun datar lingkaran.

P4001 Mbak jadi kan itu kalau pengantin laki-laki pake kuluk. Kira-kira kuluk tersebut bentuknya seperti apa ya?

S4001 Bentuknya bulat di bagian penutupnya terus ada hiasan kain-kain emasnya.

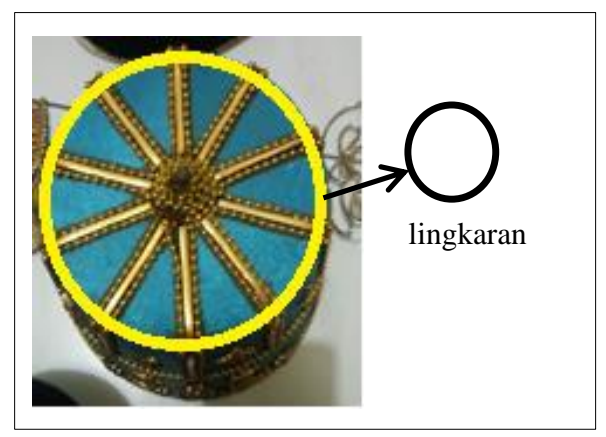

Gambar 1. Kuluk berbentuk lingkaran

S4 menyebutkan bahwa kuluk berbentuk bulat Berdasarkan hasil observasi dan wawancara dengan S4, S4 mengatakan bagian atas kuluk berbentuk bulat yang mana memiliki arti yang sama dengan lingkaran maka diperoleh kuluk memiliki konsep bangun datar yaitu lingkaran.

Selanjutnya konsep bangun datar belah ketupat muncul pada riasan pengantin wanita yang terdapat di bagian kening yang disebut cithak. Berikut merupakan cuplikan pertanyaan dan jawaban mengenai bangun datar belah ketupat.

P30010 Iya cithak itu biasanya bentuknya gimana nggeh?

S30010 Nah kalau cithak ini biasanya dibentuk kaya apa ya kotak gitu

Berdasarkan hasil observasi dan wawancara dengan S3, S3 mengatakan cithak berbentuk kotak yang mana memiliki arti yang sama dengan belah ketupat maka diperoleh cithak memiliki konsep bangun datar yaitu belah ketupat. 


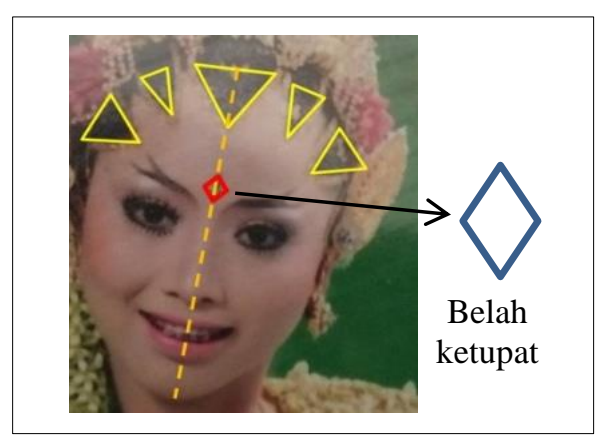

Gambar 2. cithak berbentuk belah ketupat

Konsep bangun datar selanjutnya adalah segitiga. Bangun datar segitiga muncul pada riasan pengantin wanita yang disebut paes ageng yang berasal dari penggabungan titik-titik yang sudah diukur menggunakan jari perias. Hal ini dapat dilihat dari hasil wawancara berikut.

P4007 Selanjutnya untuk riasan pengantin paes ageng-nya itu bagaimana nggeh?

S4007 Itu ada godhek, penitis, penunggul sama pengapit.

P4008 Itu gimana ya mbak mbuatnya?

S4004 Pertama-tama dibuat dulu penunggulnya yang paling besar di tengah. Ambil titik tengahnya terus dibuat lebar 3 jari dengan jari tengah pas di titik tengah. Selanjutnya kurang lebih sama lebarnya saja yang beda-beda kalau pengapit itu lebarnya 2,5jari, penitis 3jari dan godhegnya 2 jari. Tiap sela-sela cengkorongan tadi dikasi jarak setengah bagian. Terus setelah diukur, ditandai dengan titik-titik menggunakan alis terus digambar garis jadi membentuk kaya segitiga.

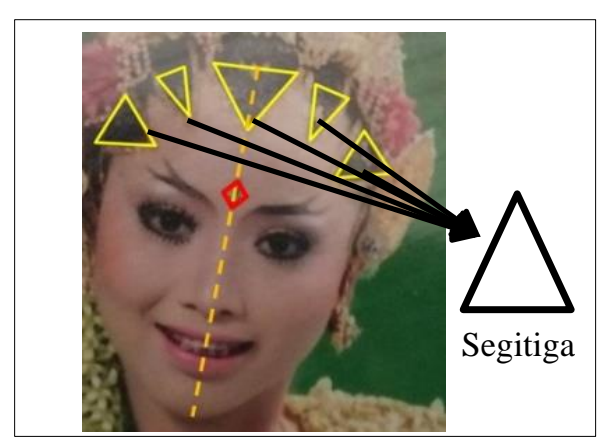

Gambar 3. Paes Ageng

Dari hasil wawancara dan observasi tersebut dapat kita lihat bahwa hasil dari penggabungan 3 titik menghasilkan sebuah bangun datar segitiga.

Bangun datar berikutnya adalah poligon yang ditemukan pada bagian suweng pada bagian bingkai suweng. 


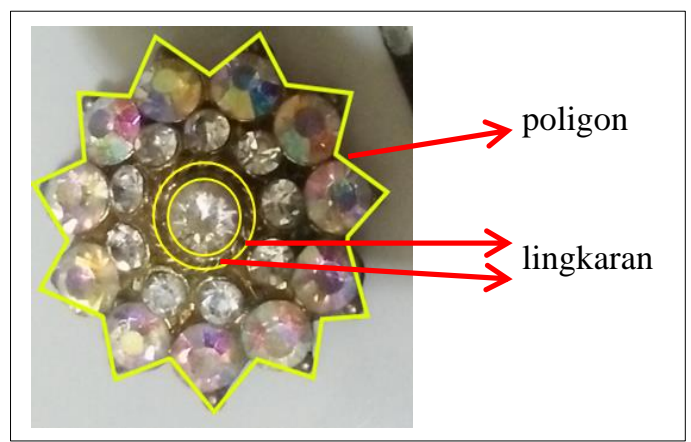

Gambar 4. Suweng

\section{Analisis Konsep Transformasi Geometri}

Konsep transformasi geometri muncul pada bentuk-bentuk dari riasan dan atribut bagian kepala paes ageng diantaranya gambar paes ageng, kuluk, sumping, suweng, centhung dan sisir gunungan. Terdapat dua macam konsep transformasi geometri yang ditemukan pada penelitian ini yaitu, konsep transformasi geometri translasi dan pencerminan.

Berdasarkan hasil observasi oleh peneliti penggunaan konsep transformasi geometri refleksi (pencerminan) ditemukan pada kuluk, paes ageng, sumping, suweng, dan centhung. Pada kuluk terdapat pada bagian pita-pita yang membagi kuluk sama besar. Pada paes ageng, sumping, suweng, dan centhung terlihat pada pemasangannya yang dibuat sejajar.

Setelah melakukan observasi, selanjutnya dilakukan wawancara kepada S3. Berdasarkan hasil wawancara dengan S3 diperoleh bahwa terdapat konsep transformasi geometri pada kuluk. S3 mengatakan ada payet (pita emas) yang membagi kuluk. Hal ini dapat dilihat pada cuplikan wawancara dengan S3 selaku perias sebagai berikut.

P3002 Kuluk paes ageng itu bentuknya gimana ya bu?

S3002 Bentuknya bulat terus ada payet nya ada bagian depan sama bagian belakang. Terus yang ada batasannya plisir itu tandanya bagian belakang. Kuluk ini ada macem-macem warna. Hitam, emas, biru. Nah kalau kuluk untuk paes ageng ini warnanya biru.

Berdasarkan hasil observasi dan wawancara dengan S3 diperoleh bahwa S3 mengatakan terdapat payet yang memberi batasan bagian depan dan belakang memotong bagian kuluk sama besar. Maka dari itu kuluk menggunakan konsep transformasi geometri yaitu refleksi (pencerminan).

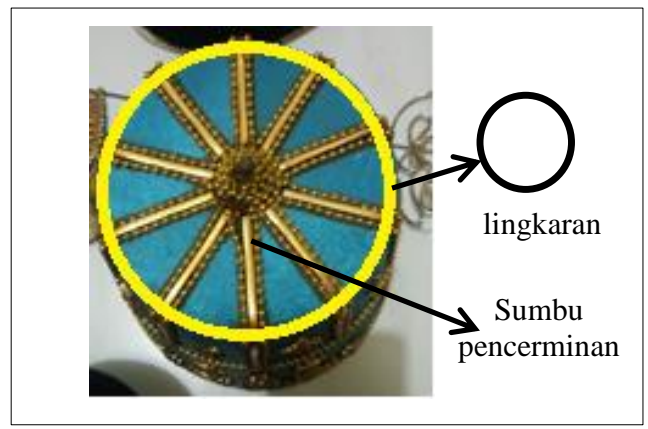

Gambar 5. Kuluk 
Selanjutnya konsep transformasi geometri translasi. Konsep ini ditemukan ketika perias memberi jarak dua jari pada masing-masing sela-sela cunduk menthul. Hal ini dapat dilihat pada cuplikan wawancara dengan S3 selaku perias sebagai berikut.

P3016 Terus kalau misal yang cunduk menthul ini kan bentuknya seperti apa ya?

S3016 Bentuknya seperti bunga

P3017 Cara memasang di kepala supaya pas ditengah apa ada caranya?

S3017 Jadi itu ada ukurannya. Diantara sela-selanya diberi jarak dua jari. Nah kalau Paes ageng itu jumlah nya 5.

P3018 Jadi di pasang satu ditengah dulu baru dua jari dua jari bagian sampingnya?

S3018 Iya. Lalu sela-sela nya diberi jarak dua jari.

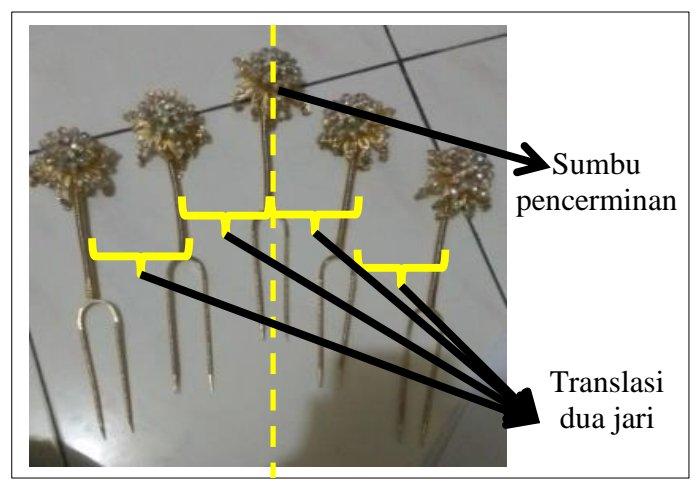

Gambar 6. Cunduk Menthul

Berdasarkan hasil observasi dan wawancara dengan S3 diperoleh bahwa S3 mengatakan sebelum memasang cunduk menthul terlebih dahulu menentukan titik tengah agar didapatkan hasil yang sejajar sehingga jika dikaitkan dengan konsep Matematika, paes ageng berkaitan dengan konsep transformasi geometri yaitu refleksi (pencerminan) kemudian pemberian jarak dua jari pada setiap sela-sela cunduk menthul tersebut berkaitan dengan konsep transformasi geometri yaitu translasi.

Etnomatematika yang terdapat pada beberapa bentuk atribut bagian kepala pengantin paes ageng. Berdasarkan hasil observasi dan wawancara didapatkan unsur etnomatematika yang terkandung dalam atribut bagian kepala pengantin paes ageng berupa kuluk, sumping, paes ageng cithak, cunduk menthul, centhung sisir gunungan, dan suweng. Diantaranya adalah bentuk yang menyerupai bangun datar lingkaran, belah ketupat, segitiga dan segi banyak (polygon). Selain itu juga didapatkan konsep transformasi geometri yaitu translasi dan pencerminan (refleksi).

Penelitian ini menemukan konsep bangun datar lingkaran, belah ketupat, segitiga dan segi banyak (polygon). Konsep bangun datar lingkaran ditemukan pada kuluk, sumping, sisir gunungan, dan suweng. Bentuk lingkaran ini ditemukan dengan beberapa ukuran. Dari hasil wawancara dengan S3 dan S4 bentuk lingkaran sering disebut dengan kata ganti 'bulat' dan 'melingkar' yang memiliki arti yang sama dengan lingkaran. Selanjutnya konsep bangun datar segitiga ditemukan pada gambar paes ageng yang dilukir di dahi penganti wanita dengan mula-mula menentukan titik-titik sebelum menyambungkannya dengan garis lurus. Dan konsep bangun datar belah ketupat ditemukan pada gambar cithak yang terletak diantara kedua alis. Dari hasil wawancara tersebut didapatkan bentuk belah ketupat disebut dengan 'kothak' oleh perias yang merujuk pada belah ketupat. Hal ini sejalan 
dengan penelitian yang dilakukan oleh Krisnawati (2017) yang mengacu pada materi SMP bangun datar dalam Kajian Etnomatematika Terhadap Tradisi Pernikahan Yogyakarta, dan juga sejalan dengan penelitian yang dilakukan oleh Maure (2018) yang mengacu pada bentuk geometri dalam Eksplorasi Etnomatematika pada Tarian Caci Masyarakat Mangarai Nusa Tenggara Timur.

Penelitian selanjutnya yang relevan dengan hasil penelitian ini adalah penelitian yang dilakukan oleh Rahmani dkk. (2018) yang berjudul "Eksplorasi Etnomatematika Ritual Seblang Olehsari Terhadap Konsep Geometri" yang terkait dengan konsep transformasi geometri. Hal ini sesuai dengan penelitian ini yaitu ditemukan konsep transformasi geometri refleksi dan translasi. Konsep refleksi ditemukan pada kuluk, sumping, sisir gunungan, suweng, centhung, dan cunduk menthul. Dari hasil observasi konsep pencerminan ini sering disebutkan dengan kata 'sejajar' dan 'sama kanan dan kiri'. Terakhir konsep translasi ditemukan pada cunduk menthul dari hasil wawancara setelah memasang satu Cundhuk Menthul di tengah perias memberi jarak dua jari. Jarak dua jari antar cunduk menthul ini sesuai dengan konsep transformasi geometri yaitu traslasi. Berikut ini merupakan tabel unsur-unsur etnomatematika pada riasan dan atribut bagian kepala paes ageng.

Tabel 1. Unsur-Unsur Etnomatematika pada Riasan dan Atribut bagian Kepala Paes ageng

\begin{tabular}{|c|l|l|}
\hline No & \multicolumn{1}{|c|}{ Nama Objek } & \multicolumn{1}{|c|}{ Unsur Matematika } \\
\hline 1. & Kuluk, sumping, sisir gunungan, dan suweng & Lingkaran \\
\hline 2. & Cithak & Belah ketupat \\
\hline 3. & Gambar Paes ageng & Segitiga \\
\hline 4. & Suweng & Segibanyak (polygon) \\
\hline 5. & Cunduk menthul & Translasi \\
\hline 6. & $\begin{array}{l}\text { Kuluk, sumping, paes ageng, Cithak, cunduk } \\
\text { menthul, centhung sisir gunungan, dan suweng }\end{array}$ & Refleksi \\
\hline
\end{tabular}

Etnomatematika riasan dan atribut bagian kepala paes ageng yakni konsep transformasi geometri dan bangun datar akan dijadikan bahan untuk membuat paket tes siswa untuk kelas XI SMA. Pada paket tes siswa ini diangkat pokok bahasan yang paling banyak muncul setelah penelitian Paket tes siswa terkait etnomatematika riasan dan atribut bagian kepala paes ageng dapat diakses melalui tautan berikut ini. https://tinyurl.com/PaketTesSiswaEtno.

\section{Kesimpulan}

Berdasarkan hasil analisis dan pembahasan, dapat diambil kesimpulan bahwa pada riasan dan atribut paes ageng ditemukan etnomatematika di dalamnya yaitu adanya unsur matematika khususnya konsep geometri. Etnomatematika muncul pada riasan dan atribut paes ageng. Adapun unsur atau konsep geometri, yang terdapat pada atribut paes ageng yaitu pada pengantin wanita diantaranya sumping, paes ageng, cithak, cunduk menthul, centhung, sisir gunungan, dan suweng sedangkan pada pengantin pria yaitu kuluk dan sumping. Unsur atau konsep geometri yang terdapat pada riasan dan atribut Paes ageng yakni konsep bangun datar dan transformasi geometri. Pada konsep bangun datar ditemukan bentuk bangun lingkaran, segitiga, polygon dan belah ketupat. Pada konsep transformasi geometri terdapat translasi dan refleksi. Bentuk lingkaran ditemukan pada kuluk, sumping, paes ageng cithak, sisir gunungan, dan suweng. Bentuk segitiga ditemukan pada paes ageng bermula dari membuat titik-titik yang sudah dibuat oleh perias menggunakan alat ukur tangan, lalu titik-titik 
tersebut disatukan hingga membentuk segitiga sama kaki. Kemudian pada bentuk poligon ditemukan pada suweng atau giwang bagian dalam. Dan pada belah ketupat ditemukan pada cithak. Pada konsep transformasi geometri translasi ditemukan pada pemasangan cunduk menthul yang memiliki bentuk sama dipasang dengan jarak dua jari antar cunduk menthul. Konsep trnsformasi geometri refleksi ditemukan pada kuluk, sumping, paes ageng, cithak, cunduk menthul, centhung sisir gunungan, dan suweng. Kemudian dari hasil tersebut dihasilkan paket tes berbentuk soal isian sebanyak 7 soal untuk kelas XI SMA terkait konsep matematika yang telah ditemukan.

\section{Daftar Pustaka}

Alders, C. J., dan Soemantri. (1980). Ilmu Ukur Ruang. Jakarta: Pradnya Paramitha.

Burger, W. F., dan Shayghnessy, J. M. (1986). Characterizing the Van Hiele levels of development in geometry. Journal for Research in Mathematics Education, 171: 31-48.

D’Ambrosio, U. (2006). Ethnomathematics: Link between Traditions and Modernity. Rotterdam: Sense Publishers.

Harsya, I., dan Ernawaty. (2017). Implementasi Peratutan Daerah Nomor 21 Tahun 2012 Tentang Pengelolaan Sampah di Kecamatan Padang Utara Kota Padang. Jurnal UNRI. 41: 1-13.

Krisnawati, Y. (2017). Kajian Etnomatematika Terhadap Tradisi Pernikahan Yogyakarta oleh Masyarakat di Kecamatan Minggir, Sleman, DIY, dalam Rangka Penentuan Aspek-Aspek Matematis yang Dapat Digunakan dalam Pembelajaran Matematika di SMP. Tesis. Yogyakarta: Pascasarjana Universitas Sanata Dharma.

Marshall, C., dan G. Rossman. (1995). Designing Qualitative Research. California: Sage Publication, Inc.

Maure, P. O., dan G. P. Ningsi. (2018). Eksplorasi Etnomatematika pada Tarian Caci Masyarakat Mangarai Nusa Tenggara Timur. Prosiding Seminar Nasional Etnomatnesia. 9 Desember 2017: 340-347.

Nazir, M. (2003). Metode Penelitian. Bogor: Ghalia Indonesia.

Rahmani, P. A., Susanto, L. A. Monalisa,, Hobri, R. P. Murtikusuma. (2018). Eksplorasi Etnomatematika Ritual Seblang Olehsari Terhadap Konsep Geometri. Jurnal UNEJ. 9(2). 43: 108-117.

Ruseffendi, E.T. (1991). Pengantar Kepada Membantu Guru Mengembangkan Kompetensinya dalam Pengajaran Matematika untuk Meningkatkan CBSA. Bandung: Tarsito.

Sarwono, J. (2006). Metode Penelitian Kualitatif dan Kuantitatif. Edisi Pertama. Yogya: Graha Ilmu. 